\title{
Pengaruh Tingkat Suku Bunga, Nilai Tukar, Inflasi dan Return on Assets (ROA) terhadap Harga Saham pada Sub-Sektor Perbankan Di Bursa Efek Indonesia Tahun 2016-2019
}

\author{
Jessica*, Michelle, Wirda Lilia \\ Jurusan Akutansi Keuangan, Fakultas Ekonomi, Universitas Prima Indonesia, Medan \\ *Correspondence email: jessica.taann.jt@gmail.com, miichellechen21@gmail.com, liliawirda@ymail.com
}

\begin{abstract}
Abstrak. Penelitian ini memiliki tujuan untuk mengetahui Pengaruh Tingkat Suku Bunga, Inflasi, Nilai tukar, dan Return On Assets (ROA) Terhadap Harga Saham pada Sub-Sektor Perbankan di Bursa Efek Indonesia periode 2016-2019. Data yang digunakan bersumber dari data keuangan di Bursa Efek Indonesia melalui situs www.idx.co.id, dan telah dilakukan seleksi berdasarkan kriteria yang telah ditentukan. Populasi yang digunakan dalam penelitian ini adalah perusahaan Bank yang berjumlah 46 perusahaan, dengan menggunakan purposive ample maka sampel yang didapatkan sebanyak 15 perusahaan. Dengan penelitian ini diharapkan agar dapat menjadi suatu ilmu pengetahuan untuk membantu para peneliti selanjutnya dan juga para mahasiswa atau masyarakat umum yang membutuhkan suatu sumber informasi. Dari penelitian dapat diketahui bahwa Return On Assets (ROA) secara pasrsial bepengaruh dan mengalami signifikan terhadap harga saham. Tingkat Suku Bunga, Nilai Tukar, Inflasi secara pasrsial tidak berpengaruh dan tidak mengalami signifikan terhadap harga saham pada Sub-Sektor Perbankan.Tetapi semua variable berpengaruh secara simultan.Pemilihan sektor pada penelitian ini dikarenakan saat ini Indonesia sudah memasuki era globalisasi yang lebih maju, tentunyaakan ada banyak pendatang asing maupun lokal yang pasti akan membutuhkan berbagai macam kebutuhan pokok, sehingga banyaknya usaha atau perusahaan yang dibangun atas dasar itu, yang membuat saya berniat untuk menelitinya.
\end{abstract}

Kata Kunci:Total Assets Turn Over; Debt to Assets Ratio;Debt To Equity Ratio;Return On Assets; Stock Price

Abstract. This research has a purpose of knowing the effect of Interest Rate, Exchange Rate, Inflation, and Return OnAsset. Against the Share Price on Banking Sub-Sector in Indonesia Stock Exchange period 2016-2019. The Data used is source by financial data in Indonesia Stock Exchange through www.idx.co.id, and has been selected based on predetermined criteria. Population used in this research is bank companies which is 46 companies. We used purposive sample, so the sample was 15 companies. With this research, it is hoped that it can become a science to help the next researcher and also college student or general public who need information. In this research, we know that Return On Asset is partially influential and significant with share price. Interest rate, exchange rate, inflation partially has no effect and not significant with share price on Banking SubSector. But all the variables effect simultaneously. Selection of sector in this research is because Indonesia has been more advanced era of globalization, of course there will be many foreigners nor a local who will need various kinds of basic needs, so many companies built because of that basis. That's why we intend to research this topic.

Keywords: Total Assets Turn Over; Debt to Assets Ratio; Debt To Equity Ratio; Return On Assets; Stock Price

\section{PENDAHULUAN}

Menurut Lisnawati (2011), Perkembangan pasar modal di Indonesia sangat pesat. Modal merupakan komponen yang tidak dapat dipisahkan dari aktivitas pembangunan ekonomi. Bagi negara berkembang, kecukupan modal cenderung menjadi masalah. Untuk mendapatkan modal, perusahaan dapat menerbitkan dan menjual sekuritas pasar modal untuk menjaring dana dari masyarakat. Dengan adanya pasar modal maka pihak yang memiliki kelebihan dana dapat menginvestasikan dana tersebut dengan harapan dapat memperoleh imbalan berupa deviden, sedangkan pihak perusahaan dapat memanfaatkan dana tersebut untuk kepentingan investasi tanpa menunggu tersedianya dana dari kegiatan operasi perusahaan.

Menurut Sulia (2017), Perkembangan harga saham di pasar modal merupakan suatu indikator penting untuk mempelajari tingkah laku pasar yaitu investor. Investor akanmendasarkan keputusan investasinya pada informasi - informasi yang dimilikinya termasuk informasi keuangan perusahaan. Informasi keuangan yang digunakan untuk menganalisis harga saham antara lain price to book value, price earning ratio, dan pertumbuhan aset.

Menurut Suramaya (2012), Lingkungan ekonomi makro merupakan lingkungan yang mempengaruhi operasi perusahaan sehari-hari. Kemampuan investor dalam memahami dan meramalkan kondisi ekonomi makro di masa datang akan sangat berguna dalam pembuatan keputusan investasi yang menguntungkan. Untuk itu, seorang investor harus mempertimbangkan beberapa indikator ekonomi makro yang bisa membantu investor dalam membuat keputusan investasinya.

Menurut Catur Fatchu Ukhriyawati (2018), Return On Asset (ROA) merupakan rasio antar laba bersih yang berbanding terbalik dengan keseluruhan aktiva untuk menghasilkan laba. Rasio ini menunjukan berapa besar laba bersih yang diperoleh perusahaan 
diukur dari nilai aktivanya. Analisis Return On Assets atau sering diterjemahkan dalam bahasa Indonesia sebagai rentabilitas ekonomi mengukur perkembangan perusahaan menghasilkan laba pada masa lalu. Analisis ini kemudian diproyeksikan ke masa mendatang untuk melihat kemampuan perusahaan menghasilkan laba pada masa mendatang. Return On Asset menggambarkan perputaran aktiva diukur dari penjualan. Semakin besar rasio ini maka semakin baik dan hal ini berarti bahwa aktiva dapat lebih cepat berputar dan meraih laba.

Menurut Fitri (2018), Salah satu patokan dalam berinvestasi salah satunya yaitu kemudahan memperoleh informasi mengenai perkembangan harga saham di bursa efek. Informasi yang diperoleh merupakan hal yang dibutuhkan investor yang hendak melakukan investasi, beberapa informasi dapat dijadikan sebagai acuan sebelum melakukan transaksi berinvestasi pada pasar modal diantaranya inflasi, suku bunga, nilai tukar, fluktuasi harga, volume perdagangan, informasi penting terhadap emiten dan lain-lain.

Menurut Vicky (2018), Salah satu informasi yang di perlukan masyarakat untuk mengetahui informasi yang lebih lengkap mengenai perkembangan bursa yang semakin meningkat adalah indeks harga saham sebagai cerminan dari pergerakan harga saham. Bursa efek memberikan informasi lengkap harga saham melalui media cetak dan elektronik. Melihat adanya inkonsistensi korelasi antara teori dengan realita di lapangan mengenai variabel ekonomi makro yaitu tingkat suku bunga yang mempengaruhi harga saham di sektor pertambangan, maka peneliti tertarik untuk melakukan penelitian tentang pengaruh tingkat suku bunga terhadap harga saham.

Setelah penelitian dapat diketahui PT. Bank Central Asia, Tbk ditemukan data bahwa Tingkat Suku Bunga pada tahun 2016 sebesar $4,75 \%$ dan mengalami penurunan pada tahun 2017 menjadi 4,25\%. Sedangkan Inflasi pada tahun 2016 sebesar 3,00\% mengalami kenaikan pada tahun 2017 menjadi 3,60\%. Data tabel fenomena tersebut sesuai dengan pernyataan bahwa apabila inflasi meningkat maka tingkat suku bunga akan menurun.

Pada PT. Bank Mandiri (Persero), Tbk ditemukan data bahwa Inflasi pada tahun 2017 sebesar 3,60\% dan mengalami penurunan pada tahun 2018 menjadi 3,07\%. Sedangkan Return On Asset pada tahun 2017 sebesar 2,72\% mengalami kenaikan pada tahun 2018 menjadi $3,17 \%$. Data tabel fenomena tersebut sesuai dengan pernyataan bahwa apabila inflasi meningkat maka Return On Assetakan menurun.

Menurut Elvinia (2018), terdapat 2 penjelasan mengapa kenaikan suku bunga dapat mendorong harga saham ke bawah. Pertama, kenaikan suku bunga mengubah peta hasil invesatasi. Kedua, kenaikan suku bunga akan memotong laba perusahaan.
Menurut Vira (2010), bahwa tingkat suku mempengaruhi harga saham secara terbalik (Cateris Paribus). Bila pemerintah mengumumkan tingkat suku bunga yang lebih tinggi maka investor akan menjual sahamnya dan beralih berinvestasi pada sektor perbankan seperti deposito dan tabungan.

Menurut Akbar Faoriko (2013), adanya kenaikan Suku Bunga yang tidak wajar akan menyulitkan dunia usaha untuk membayar beban bunga dan kewajiban, karena Suku Bunga yang tinggi akan menambah beban bagi perusahaan sehingga secara langsung akan mengurangi profit perusahaan.

H1 : Tingkat suku bunga berpengaruh terhadap harga saham

Depresiasi kurs mata uang domestik terhadap mata uang asing dapat meningkatkan volume ekspor. Hal ini dapat meningkatkan profitabilitas perusahaan yang kemudian meningkatkan harga saham perusahaan apabila permintaan pada pasar international cukup elastis dan mempengaruhi return yang akan di terima oleh investor (Ridwan Maronrong, 2017).

Jika kondisi nilai tukar Rupiah diperkirakan buruk, maka kemungkinan besar refleksi pada indeks harga saham yang akan menurun. Hal ini karena pelemahan kurs Rupiah terhadap mata uang asing merupakan sinyal negatif bagi investor sehingga akan mempengaruhi harga saham tersebut (Denny Andriana, 2015).

Perubahan satu variabel makro ekonomi memiliki dampak yang beda terhadap berbagai jenis saham, yaitu suatu saham bisa terkena dampak positif sedangkan saham lain bisa terkena dampak negatif dari kenaikan nilai tukar. Kenaikan Kurs Dollar US yang tajam terhadap rupiah akan berdampak negatif terhadap emitem yang memiliki hutang dalam Dollar US sementara produk emitem tersebut dijual secara lokal. Sementara itu, emitem yang berorientasi di pasar ekspor akan menerima dampak positif dari kenaikan Kurs Dollar US tersebut. Sehingga dapat diartikan bahwa harga saham emitem 22 yang tekena dampak negatif akan mengalami penurunan di bursa efek,dan emitem yang terkena dampak positif akan mengalami peningkatan harga sahamnya (Kausar Akbar,2018). $\mathrm{H} 2$ : Nilai tukar berpengaruh terhadap harga saham

Menurut Putu (2017), bahwa inflasi yang tinggi akan menjatuhkan harga saham di pasar. Sementara inflasi yang rendah akan berakibat pertumbuhan ekonomi yang sangat lamban dan pada akhirnya harga saham juga bergerak dengan lamban.

Menurut Ni Kadek Suriyani (2018), menyatakan bahwa inflasi merupakan kecenderungan terjadinya peningkatan harga produk-produk secara ke seluruhan. Inflasi yang tinggi mengurangi tingkat pendapatan riil yang diperoleh investor dari investasi. 
Menurut Sangga Yoga Wismantara (2017), inflasi akan cenderung meningkatkan biaya produksi dari perusahaan, sehingga margin keuntungan dari perusahaan menjadi lebih rendah. Dampak lanjutan dari hal ini adalah menjadikan harga saham di bursa menjadi turun. Apabila hal ini dialami oleh banyak perusahaan di pasar modal maka kinerja IHSG juga akan menurun.

H3 : Inflasi berpengaruh terhadap harga saham

Menurut Ni Komang Santi Ani (2019), return on asset adalah rasio yang digunakan untuk mengukur keuntungan bersih yang diperoleh dari penggunaan aktiva. Dengan kata lain, semakin tinggi rasio ini maka semakin baik produktivitas aset dalam memperoleh keuntungan bersih. Hal ini selanjutnya akan meningkatkan daya tarik perusahaan kepada investor. Peningkatan daya tarik perusahaan menjadikan perusahaan tersebut semakin diminati investor, karena tingkat pengembalian akan semakin besar. Hal ini juga akan berdampak bahwa harga saham dari perusahaan tersebut di pasar modal juga akan semakin meningkat sehingga return on asset akan berpengaruh terhadap harga saham perusahaan.

Return On Assets (ROA) yang besar akan menunjukkan kinerja perusahaan yang baik, karena return yang didapatkan semakin besar. Return yang besar maka akan menarik minat investor untuk menanamkan modalnya pada perusahaan tersebut sehingga selanjutnya akan berdampak pada kenaikan harga saham (Fangky, 2019).

H4 : Return On Assets berpengaruh terhadap harga saham

\section{METODE}

\section{Jenis Penelitian}

Menggunakan metode penelitian kuantitatif. Data dalam penelitian ini adalah data sekunder yang dipublikasikan oleh Bursa Efek Indonesia. Jenis penelitian adalah deskriptif.

\section{Populasi dan Sampel}

Populasi dalam penelitian adalah perusahaan SubSektor Perbankan yang ada di Bursa Efek Indonesia dan laporan keuangan yang digunakan bersumber dari www.idnfinancials.comBerdasarkan populasi yang sudah ditentukan terdapat 46 perusahaan.

Populasidalam penelitian adalah perusahaan SubSektor Perbankan yang ada di Efek Indonesia dan laporan keuangan yang digunakan bersumber dari www.idnfinancials.com. Berdasarkan populasi yang sudah ditentukan terdapat 46 perusahaan.

Sampel adalah bagian dari populasi yang diambil sesuai dengan kriteria yang peneliti temukan. Dalam penelitian ini, teknik sampling yang digunakan adalah metode sampling purposive. Yang terdaftar di Bursa Efek Indonesia selama periode 2016-2019, dan memiliki laba positif, terdapat 15 perusahaan yang memenuhi syarat sebagai sampel dalam penelitianini

Tabel 1. Sampel Penelitian

\begin{tabular}{llc}
\hline No. & \multicolumn{1}{c}{ Kriteria } & Jumlah \\
\hline 1. & $\begin{array}{l}\text { Perusahaan sub sektor perbankan yang } \\
\text { terdaftar di BEI periode 2016-2019 }\end{array}$ & 46 \\
2. & $\begin{array}{l}\text { Perusahaan sub sektor perbankan yang } \\
\text { tidak rutin mempublikasikan laporan }\end{array}$ & \\
keuangan di BEI periode 2016-2019 \\
Perusahaan sub sektor perbankan yang \\
mengalami kerugian periode 2016-2019
\end{tabular}

Menurut Nurlina (2017), Harga saham merupakan cerminan dari kegiatan pasar modal. Kenaikan maupun penurunan harga saham merupakan cerminan dari kegiatan pasar modal. Kenaikan maupun penurunan harga saham dipengaruhi oleh seberapa kuat penawaran dan penjualan yang terjadi pada bursa terhadap saham tersebut. Harga saham akan naik jika semakin banyak investor yang ingin membeli suatu saham. Sebaliknya harga saham akan turun jika semakin banyak investor yang ingin menjual saham tersebut

Menurut Yuliawan (2016), suku bunga adalah biaya yang harus dibayar oleh peminjam atas pinjaman yang diterima dan merupakan imbalan bagi pemberi pinjaman atas investasinya. Suku bunga mempengaruhi keputusan individu terhadap pilihan membelanjakan uang lebih banyak atau menyimpan uangnya dalam bentuk tabungan. Suku bunga juga merupakan sebuah harga yang menghubungkan masa kini dengan masa depan, sebagaimana harga lainnya maka tingkat suku bunga ditentukan oleh interaksi antara permintaan dan penawaran.

$i=r+\pi$

Nilai tukar mata uang adalah harga/nilai mata uang suatu negara dibandingkan dengan mata uang negara lain. Dalam hal penelitian ini kurs yang dimaksud adalah nilai rupiah terhadap dollar AS (Maisaroh Fathul Ilmi, 2017).

Kurs Tengah $=\frac{\text { Kurs Beli }+ \text { Kurs Jual }}{2}$

Menurut Maria (2016) definisi singkat dari inflasi adalah kecenderungan dari harga-harga yang naik secara umum dan terus menerus. Kenaikan harga dari satu atau dua barang saja tidak bisa disebut dengan inflasi.

$\operatorname{IRx}=(\operatorname{IHKx} / \mathrm{IHKx}-1.100)-100$

Return On Assets (ROA) adalah rasio keuangan perusahaan yang berhubungan dengan profitabilitas 
mengukur kemampuan perusahaan menghasilkan keuntungan atau laba pada tingkat pendapatan, aset dan modal saham tertentu (Fiona Mutiara Efendi, 2018).

ROA= Laba Bersih : Total Asset

\section{Uji Asumsi Klasik}

\section{Uji Normalitas}

Menurut Ghozali (2016), uji normalitas digunakan dalam pengujian model regresi, variabel pengganggu atau residual memiliki distribusi normal. Dimana uji $\mathrm{t}$ dan f mengasumsi bahwa nilai residual mengikuti distribusi normal. Jika dilanggar maka uji statistik menjadi tidak falid untuk sampel yang kecil.

$X^{2}=\Sigma \frac{\left(\theta_{n}-E\right)}{E}$

Dimana:

X2 : Nilai X2

Oi : Nilai Observasi

Ei : Nilai Expected,interval kelas berdasarkan tabel normal dikali N (total frekuensi) (pi X N)

$\mathrm{N}$ : Banyaknya angka pada data (total frekuensi)

\section{Uji Multikolinearitas}

Menurut Ghozali (2016), uji multikolinearitas digunakan dalam pengujian model regresi apakah didalamnya terdapat korelasi antar variabel bebas. Dimana model regresi yang baik tidak memiliki korelasi antar variabel bebas. Jika saling berkorelasi maka variabel-variabel ini tidak ortogonal atau nilai korelasi antar variabel bebas sama dengan nol.

Pedoman keputusan berdasarkan nilai VIF (Variance Inflation Factor) : 1. Jika nilai VIF $<10,00$ maka artinya tidak terjadi multikolinearitas dalam model regresi. 2. Jika nilai VIF $>10,00$ maka artinya terjadi multikolineartias dalam model regresi.

\section{Uji Heteroskedastisitas}

Menurut Ghozali (2016), uji heteroskedastisitas digunakan dalam pengujian model regresi apakah terjadi ketidaksamaan variance dari residual suatu pengamatan ke pengamatan lain. Jika variance nya tetap maka disebut homoskedastisitas dan jika berbeda disebut heteroskedastisitas. Model regresi yang baik adalah homoskedastisitas atau dengan kata lain tidak terjadi heteroskedastisitas. Dasar pengambilan keputusan: 1 . Tidak terjadi heteroskedastisitas, jika nilai t hitung lebih kecil dari t tabel dan nilai signifikansi lebih besar dari 0,05. 2. Terjadi heteroskedastisitas, jika nilai t hitung lebih besar dari t tabel dan nilai signifikansi lebih kecil dari 0,05 .

\section{Uji Autokorelasi}

Menurut Ghozali (2016), uji autokorelasi digunakan dalam pengujian model regresi linear apakah terdapat korelasi antara kesalahan pengganggu pada periode $\mathrm{t}$ dengan kesalahan pengganggu periode $\mathrm{t}-1$. Jika terdapat korelasi maka dikatakan terdapat problem autokorelasi. Masalah ini timbul karena kesalahan pengganggu tidak bebas dari satu observasi ke yang lain.

$$
\begin{aligned}
& d=\frac{\sum(e i-e i-1) 2}{\sum e i} \\
& \text { Dimana: } \\
& \text { d } \quad \text { nilai durbin Watson } \\
& \sum \text { ei : jumlah kuadrat sisa }
\end{aligned}
$$

\section{Analisis Regresi Berganda}

Metode analisis data penelitian ini menggunakan analisis regresi berganda. Model regresi berganda yang digunakan adalah sebagai berikut:

$$
\begin{aligned}
& \mathrm{Y}=\mathrm{a}+\mathrm{b} 1 \mathrm{X} 1+\mathrm{b} 2 \mathrm{X} 2+\mathrm{b} 3 \mathrm{X} 3+\mathrm{b} 4 \mathrm{X} 4+\mathrm{e} \\
& \text { Keterangan: } \\
& \mathrm{Y}=\text { Harga Saham } \\
& \text { a = Harga Konstanta } \\
& \text { b1 = Koefisien Regresi Pertama } \\
& \text { b2 = Koefisien Regresi Kedua } \\
& \text { b3 = Koefisien Regresi Ketiga } \\
& \text { b4 = Koefisien Regresi Keempat } \\
& \mathrm{X} 1=\text { Variabel Tingkat Bunga } \\
& \mathrm{X} 2=\text { Variabel Nilai Tukar } \\
& \mathrm{X} 3=\text { Variabel Inflasi } \\
& \text { X4 = Variabel Return On Asset } \\
& \mathrm{e} \quad=\text { Faktor Penganggu (error) }
\end{aligned}
$$

\section{Uji T (Parsial)}

Menurut Ghozali (2016), Uji statistik t pada dasarnya bertujuan untuk menunjukkan seberapa jauh pengaruh satu variabel independen secara individual menerangkan variasi variabel dependen. Dimana hipotesis nol (Ho) tentang tidak adanya pengaruh, umumnya dirumuskan untuk ditolak. Sedangkan hipotesis alternatif (Ha) sebagai hipotesis yang diajukan dalam penelitian ini. Adapun hipotesisnya sebagai berikut: Ho: $b_{1}, b_{2}=0$, artinya tidak ada pengaruh signifikan secara parsial antara variabel independen yaitu Tingkat Suku Bunga dan Nilai Tukar terhadap variabel dependen yaitu harga saham pada sub-sektor perbankan periode 2016-2019.

\section{Uji F (Simultan/Serentak)}

Menurut Ghozali (2016), Uji statistik f pada dasarnya bertujuan untuk menunjukkan apakah semua variabel independen mempunyai pengaruh bersamasama terhadap variabel dependen. Dimana hipotesis nol (Ho) tentang tidak adanya pengaruh, umumnya dirumuskan untuk ditolak. Sedangkan hipotesis alternatif (Ha) sebagai hipotesis yang diajukan dalam penelitian ini. Adapun hipotesisnya sebagai berikut: Ho: $b_{1}, b_{2}=0$, artinya tidak ada pengaruh signifikan secara simultan antara variabel independen yaitu Tingkat Suku Bunga 
dan Nilai Tukar terhadap variabel dependen yaitu harga saham pada sub-sektor perbankan periode 2016-2019.

\section{Uji Koefisien Determinasi $\left(\mathbf{R}^{2}\right)$}

Koefisien determinasi (R2) digunakan untuk mengetahui besarnya kemampuan variabel independen dalam mempengaruhi variabel dependennya. Nilai koefisien determinasi mempunyai range 0 sampai 1.Koefisien determinasi (R2) yang digunakan dalam penilitian ini yaitu koefisien determinasi yang disesuaikan atau (Adjusted $R$ Square).

\section{HASIL DAN PEMBAHASAN}

Tabel 2. Hasil Uji Desciptive

Descriptive Statistics

\begin{tabular}{|c|c|c|c|c|c|}
\hline & $\mathrm{N}$ & Minimum & Maximum & Mean & Std. Deviation \\
\hline ln_tsb & 60 & 1.11 & 1.91 & 1.6059 & .15162 \\
\hline ln_nt & 60 & 9.50 & 9.63 & 9.5358 & .02955 \\
\hline ln_inf & 60 & .95 & 1.28 & 1.1391 & .10043 \\
\hline ln_roa & 60 & -2.04 & 1.63 & .5226 & .78239 \\
\hline ln_hs & 60 & 4.12 & 10.31 & 7.2926 & 1.50469 \\
\hline Valid N (listwise) & 60 & & & & \\
\hline
\end{tabular}

Sumber: Data diolah berikut.

Hasil dari uji Descriptive statistics adalah sebagai

a. Variabel LN_TSB memiliki sampel 60 dengan nilai minimum 1,11 dan nilai maksimum 1,91 sedangkan nilai rata-rata 1,6059 dengan standar deviasi 0,15162 .

b. Variabel LN_NT memiliki sampel 60 dengan nilai minimum 9,50 dan nilai maksimum 9,63 sedangkan nilai rata-rata 9,5358 dengan standar deviasi 0,02955.

c. Variabel LN_INF memiliki sampel 60 dengan nilai minimum 0,95 dan nilai maksimum 1,28 sedangkan nilai rata- rata 1,1391 dengan standar deviasi 0,10043 .

d. Variabel LN_ROA memiliki sampel 60 dengan nilai minimum -2,04 dan nilai maksimum 1,63 sedangkan nilai rata- rata 0,5226 dengan standar deviasi 0,78239 .

e. Variabel LN_Harga Saham memiliki sampel 60 dengan nilai minimum 4,12 dan nilai maksimum 10,31 sedangkan nilai rata- rata 7,2926 dengan standar deviasi 1,50469 .

\section{Hasil Uji Asumsi Klasik \\ Uji Normalitas}

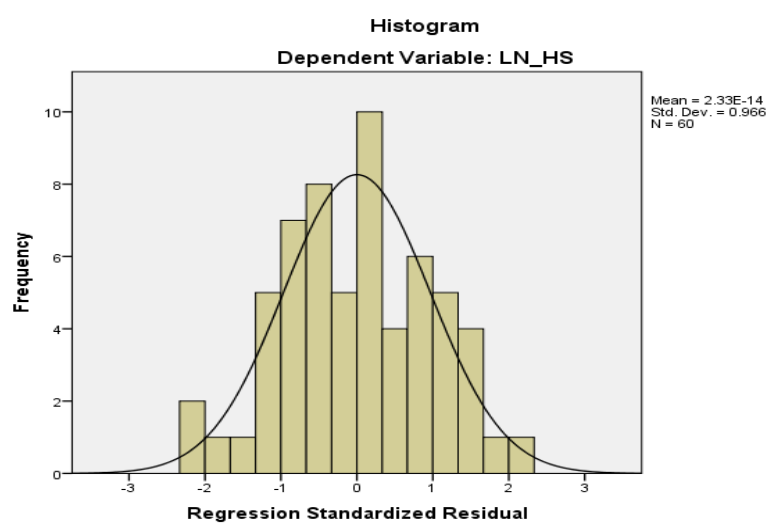

Gambar 1. Histogram

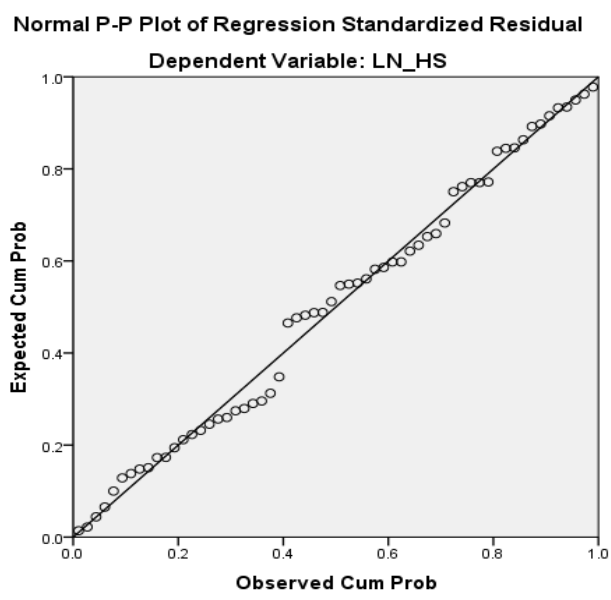

Gambar 2. Normal P-P Plot of Regression Standardized Residual

Tabel 3. Komolgrov Simirnov

One-Sample Kolmogorov-Smirnov Test

\begin{tabular}{|ll|r|}
\hline & & $\begin{array}{c}\text { Unstandardized } \\
\text { Residual }\end{array}$ \\
\hline $\mathrm{N}$ & & 60 \\
Normal Parameters & a,b & Mean \\
& Std. Deviation & $0 \mathrm{E}-7$ \\
Most Extreme & Absolute & .28282495 \\
Differences & Positive & .078 \\
Kolmogorov-Smirnov Z & Negative & .064 \\
Asymp. Sig. (2-tailed) & .601 \\
\hline
\end{tabular}

a. Test distribution is Normal.

b. Calculated from data.

Sumber: Data diolah

Berdasarkan hasil diatas Tes nilai Kolmogrov Sminov Sebesar 0,601 dan Asymp.Sig. (2-tailed) 0,862 dan nilai tersebut lebih besar dari 0,05 sehingga model residual terdistribusi secara normal. 


\section{Uji Multikolonieritas}

Tabel 4. Uji Multikolonieritas

Coefficients $^{\mathrm{a}}$

\begin{tabular}{|c|c|c|c|c|c|c|c|c|}
\hline \multirow{2}{*}{\multicolumn{2}{|c|}{ Model }} & \multicolumn{2}{|c|}{ Unstandardized Coefficients } & \multirow{2}{*}{$\begin{array}{c}\text { Standardized } \\
\text { Coefficients }\end{array}$} & \multirow[t]{2}{*}{$\mathrm{t}$} & \multirow[t]{2}{*}{ Sig. } & \multicolumn{2}{|c|}{ Collinearity Statistics } \\
\hline & & $\mathrm{B}$ & Std. Error & & & & Tolerance & VIF \\
\hline \multirow{5}{*}{1} & (Constant) & -90.280 & 71.766 & & -1.258 & .214 & & \\
\hline & ln_tsb & -1.556 & 1.522 & -.157 & -1.023 & .311 & .562 & 1.779 \\
\hline & ln_nt & 10.429 & 7.662 & .205 & 1.361 & .179 & .584 & 1.713 \\
\hline & ln_inf & .100 & 1.833 & .007 & .055 & .957 & .883 & 1.133 \\
\hline & ln_roa & .970 & .225 & .504 & 4.316 & .000 & .969 & 1.032 \\
\hline
\end{tabular}

a. Dependent Variable: $\ln \_$hs

Sumber: Data diolah

Dari hasil uji diatas nilai tolerance value semua variabel independen berada diatas 0,10 yaitu sebesar 0,562 untuk LN_TSB sebagai X1，0,584 untuk LN_NT sebagai X2, 0,883 untuk LN_INF sebagai X3, 0,969 untuk LN_ROA sebagai X4. Sedangkan nilai VIF antara variabel $\mathrm{X} 1, \mathrm{X} 2, \mathrm{X} 3, \mathrm{X} 4$ berada di bawah 10 . Jadi dapat disimpulkan bahwa penelitian ini berdasarkan nilai tolerance dan VIF tidak terjadi multikolonieritas.

\section{Uji Autokorelasi}

Tabel 5. Uji Run Test

Runs Test

\begin{tabular}{|l|r|}
\hline & Unstandardized Residual \\
\hline Test Value & -1243.47021 \\
Cases $<$ Test Value & 30 \\
Cases $>=$ Test Value & 30 \\
Total Cases & 60 \\
Number of Runs & 25 \\
Z & -1.562 \\
Asymp. Sig. (2-tailed) & .118 \\
\hline
\end{tabular}

a. Median

Sumber: Data diolah

Pengambilan keputusan dilakukan dengan melihat nilai Asymp. Sig (2-tailed) uji Run Test. Apabila nilai Asymp.Sig (2-tailed) lebih besar dari tingkat signifikansi 0,05 maka dapat disimpulkan tidak terdapat autokorelasi.Asymp. Sig (2-tailed): 0,118>0,05 (tidak terjadi autokorelasi).

\section{Uji Heteroskedastisitas}

Tabel 6. Uji Heterokedastisitas Coefficients $^{\mathbf{a}}$

\begin{tabular}{|c|c|c|c|c|c|c|c|c|}
\hline \multirow{2}{*}{\multicolumn{2}{|c|}{ Model }} & \multicolumn{2}{|c|}{ Unstandardized Coefficients } & \multirow{2}{*}{$\begin{array}{c}\text { Standardized } \\
\text { Coefficients } \\
\text { Beta }\end{array}$} & \multirow[t]{2}{*}{$\mathrm{t}$} & \multirow[t]{2}{*}{ Sig. } & \multicolumn{2}{|c|}{ Collinearity Statistics } \\
\hline & & B & Std. Error & & & & Tolerance & VIF \\
\hline \multirow{5}{*}{1} & (Constant) & 23.292 & 40.575 & & .574 & .568 & & \\
\hline & ln_tsb & .176 & .860 & .036 & .205 & .839 & .562 & 1.779 \\
\hline & ln_nt & -2.204 & 4.332 & -.088 & -.509 & .613 & .584 & 1.713 \\
\hline & ln_inf & -1.294 & 1.036 & -.175 & -1.249 & .217 & .883 & 1.133 \\
\hline & ln_roa & -.076 & .127 & -.081 & -.601 & .550 & .969 & 1.032 \\
\hline
\end{tabular}

a. Dependent Variable: abs_res2

Sumber: Data diolah

Dari hasil uji diatas didapatkan nilai SIG diatas 0,05 untuk variabel LN_TSB, LN_NT, LN_INF dan
LN_ROA yang artinya semua variabel tidak mengalami masalah Heterokedastisitas.

\section{Uji Regresi Linier Berganda}


Jessica, Michelle dan Wirda Lilia, Pengaruh Tingkat Suku Bunga, Nilai Tukar, Inflasi dan Return on Assets (ROA) terhadap Harga Saham pada Sub-Sektor Perbankan Di Bursa Efek Indonesia Tahun 2016-2019

Tabel 7. Uji Regresi Linier Berganda

Coefficients $^{\mathbf{a}}$

\begin{tabular}{|c|c|c|c|c|c|c|c|c|}
\hline \multirow{2}{*}{\multicolumn{2}{|c|}{ Model }} & \multicolumn{2}{|c|}{ Unstandardized Coefficients } & \multirow{2}{*}{$\begin{array}{c}\text { Standardized } \\
\text { Coefficients } \\
\text { Beta }\end{array}$} & \multirow[t]{2}{*}{$\mathrm{t}$} & \multirow[t]{2}{*}{ Sig. } & \multicolumn{2}{|c|}{ Collinearity Statistics } \\
\hline & & $\mathrm{B}$ & Std. Error & & & & Tolerance & VIF \\
\hline \multirow{5}{*}{1} & (Constant) & -90.280 & 71.766 & & -1.258 & .214 & & \\
\hline & ln_tsb & -1.556 & 1.522 & -.157 & -1.023 & .311 & .562 & 1.779 \\
\hline & ln_nt & 10.429 & 7.662 & .205 & 1.361 & .179 & .584 & 1.713 \\
\hline & ln_inf & .100 & 1.833 & .007 & .055 & .957 & .883 & 1.133 \\
\hline & ln_roa & .970 & .225 & .504 & 4.316 & .000 & .969 & 1.032 \\
\hline
\end{tabular}

a. Dependent Variable: $\ln \_$hs

Sumber: Data diolah

Dari hasil diatas diperoleh persamaan regresi sebagai berikut:

$\mathrm{Y}=\mathrm{a}+\mathrm{b} \times 1+\mathrm{b} \times 2+\mathrm{b} \times 3+\mathrm{b} \times 4+\mathrm{e}$

$\mathrm{Y}=-90,280-1,556 \times 1+10,429 \times 2+0,10 \times 3+0,97 \times 4+\mathrm{e}$

\section{Uji Koefisien Determinasi}

Tabel 8. Uji Koefisien Determinasi Model Summary ${ }^{b}$

\begin{tabular}{|l|r|r|r|r|}
\hline Model & \multicolumn{1}{|c|}{$\mathrm{R}$} & $\begin{array}{c}\mathrm{R} \\
\text { Square }\end{array}$ & $\begin{array}{c}\text { Adjusted R } \\
\text { Square }\end{array}$ & $\begin{array}{c}\text { Std. Error of the } \\
\text { Estimate }\end{array}$ \\
\hline 1 & $.523^{\mathrm{a}}$ & .273 & .220 & 1.32865 \\
\hline
\end{tabular}

a. Predictors: (Constant), ln_roa, ln_tsb, ln_inf, ln_nt

b. Dependent Variable: $\ln \_$hs

Sumber: Data diolah

Dari hasil data diatas dapat diperoleh nilai $\mathrm{R}$ square sebesar 0,273 atau 27,3\%. Yang artinya harga saham mampu menjelaskan nilai X1,X2,X3 dan X4. Sedangkan sisanya $72.7 \%$ dijelaskan oleh variabel lain yang tidak diteliti dalam penelitian ini.

Uji F

Tabel 9. Uji F

ANOVA $^{a}$

\begin{tabular}{|ll|r|r|r|r|r|}
\hline Model & & Sum of Squares & df & Mean Square & F & Sig. \\
\hline \multirow{2}{*}{1} & Regression & 36.488 & 4 & 9.122 & 5.167 & \\
& Residual & 97.093 & 55 & 1.765 & $.001^{\mathrm{b}}$ \\
& Total & 133.581 & 59 & & \\
\end{tabular}

a. Dependent Variable: ln_hs

b. Predictors: (Constant), ln_roa, ln_tsb, ln_inf, ln_nt

Sumber: Data diolah

Dari hasil uji diatas diperoleh nilai $F_{\text {hitung }}$ sebesar 5,167 dengan $F_{\text {tabel }}$ 2,76. Dan nilai signifikan sebesar 0,001 . Artinya nilai $5,167>2,76$ artinya variabel independen berpengaruh secara simultan terhadap variabel dependen (harga saham).

\section{Uji T}

Tabel 9. Uji T

Coefficients $^{\mathrm{a}}$

\begin{tabular}{|c|c|c|c|c|c|c|c|c|}
\hline \multirow{2}{*}{\multicolumn{2}{|c|}{ Model }} & \multicolumn{2}{|c|}{ Unstandardized Coefficients } & \multirow{2}{*}{$\begin{array}{c}\text { Standardized } \\
\text { Coefficients }\end{array}$} & \multirow[t]{2}{*}{$\mathrm{t}$} & \multirow[t]{2}{*}{ Sig. } & \multicolumn{2}{|c|}{ Collinearity Statistics } \\
\hline & & $\mathrm{B}$ & Std. Error & & & & Tolerance & VIF \\
\hline \multirow{5}{*}{1} & (Constant) & -90.280 & 71.766 & & -1.258 & .214 & & \\
\hline & ln_tsb & -1.556 & 1.522 & -.157 & -1.023 & .311 & .562 & 1.779 \\
\hline & ln_nt & 10.429 & 7.662 & .205 & 1.361 & .179 & .584 & 1.713 \\
\hline & ln_inf & .100 & 1.833 & .007 & .055 & .957 & .883 & 1.133 \\
\hline & ln_roa & .970 & .225 & .504 & 4.316 & .000 & .969 & 1.032 \\
\hline
\end{tabular}

b. Dependent Variable: $\ln \_$hs

Sumber: Data diolah 
berikut.

Hasil dari pembahasan Uji $\mathrm{T}$ adalah sebagai

a. Secara parsial uji T untuk TSB terhadap harga saham adalah nilai $\mathrm{T}_{\text {hitung }}$ sebesar $-1,023$ sedangkan nilai $\mathrm{T}_{\text {tabel }} 2,00324$. Maka $-1,023<2,00324$ dengan nilai singnifikan $0,311>0,05$. Artinya TSB tidak memiliki pengaruh terhadap harga saham dan signifikan.

b. Secara parsial uji T untuk NT terhadap harga saham adalah nilai $\mathrm{T}_{\text {hitung }}$ sebesar 1,361 sedangkan nilai $\mathrm{T}_{\text {tabel }}$ 2,00324. Maka 1,361 < 2,00324 dengan nilai singnifikan $0,179>0,05$. Artinya NT tidak memiliki pengaruh terhadap harga saham dan signifikan.

c. Secara parsial uji T untuk INF terhadap harga saham adalah nilai $\mathrm{T}_{\text {hitung }}$ sebesar 0,055 sedangkan nilai $\mathrm{T}_{\text {tabel }} 2,00324$. Maka $0,055<2,00324$ dengan nilai singnifikan $0,957>0,05$. Artinya INF tidak memiliki pengaruh terhadap harga saham dan signifikan.

d. Secara parsial uji T untuk ROA terhadap harga saham adalah nilai $\mathrm{T}_{\text {hitung }}$ sebesar 4,316 sedangkan nilai $\mathrm{T}_{\text {tabel }}$ 2,00324. Maka 4,316> 2,00324 dengan nilai singnifikan $0,000<0,05$. Artinya ROA memiliki pengaruh terhadap harga saham dan tidak signifikan.

\section{Pembahasan}

Hasil pengujian secara parsial menunjukkan bahwa Tingkat Suku Bunga berpengaruh negatif dan signifikan terhadap Harga Saham. Pengujian ini sejalan dengan penelitian Ni Kadek Suriyani (2018), dimana tingkat bunga yang tinggi akan meningkatkan biaya produksi, sehingga akan menyebabkan meningkatnya harga jual barang sehingga minat akan barang tersebut menjadi menurun yang berdampak langsung pada keuntungan penjualan. Menurut Karim (2015) suku bunga yang rendah akan menyebabkan biaya peminjaman yang lebih rendah. Suku bunga yang rendah akan merangsang investasi dan aktivitas ekonomi yang akan menyebabkan harga saham meningkat.

Hasil pengujian secara parsial menunjukkan bahwa Nilai Tukar berpengaruh negatif dan signifikan terhadap Harga Saham. Pengujian ini sejalan dengan penelitianHarsono dan Worokinasih (2018) yang menunjukkan bahwa kurs rupiah berpengaruh negatif dan signifikan terhadap indeks harga saham. Tidak adanya pengaruh yang signifikan ini mengindikasikan bahwa besar kecilnya nilai tukar rupiah pada periode bulanan tahun 2016 - 2019 tidak berdampak besar pada naik turunnya harga saham. Tidak adanya pengaruh yang signifikan ini disebabkan karena sektor perbankan menggunakan mata uang rupiah dalam melakukan transaksi dengan nasabahnya sehingga nilai tukar ruiah terhadap dollar tidak berpengaruh pada harga saham perusahaan (Saripudin, 2017).

Hasil pengujian secara parsial menunjukkan bahwa Inflasi berpengaruh negatif dan signifikan terhadap Harga Saham. Hal tersebut terjadi karena perusahaan mampu menjaga kepercayaan investor dengan baik, dengan tetap menjaga kestabilan kinerja keuangan perusahaannya. Dari uraian tersebut dapat disimpulkan bahwa inflasi tidak berpengaruh dan tidak signifikan terhadap harga saham perusahaan sub sektor perbankan yang terdaftar di Bursa Efek Indonesia. Hal ini sejalan dengan penelitian yang dilakukan oleh Linzzy (2017) mengatakan bahwa tingkat inflasi tidak ada pengaruh positif terhadap harga saham.

Hasil pengujian secara parsial menunjukkan bahwa Return On Assets berpengaruh dan signifikan terhadap Harga Saham. Hasil penelitian ini sesuai dengan penelitian yang dilakukan oleh $\mathrm{Hj}$. Erviva Fariantin (2019) yang mengatakan bahwa ROA berpengaruh signifikan terhadap harga saham. Menyatakan bahwa Return On Assets berpengaruh dan signifikan terhadap Harga Saham. Menurut Ningsih Hikmawati (2018) return on assets berpengaruh positif terhadap return saham. Hasil penelitian ini membuktikan bahwa semakin tinggi return on assets, maka semakin tinggi pula kemampuan suatu perusahaan dalam menghasilkan suatu laba. Dan nilai rasio return on assets yang tinggi berarti perusahaan tersebut semakin efisien dalam memanfaatkan aktivanya untuk memperoleh suatu laba, maka return saham akan meningkat.

\section{SIMPULAN}

Berdasarkan hasil penelitian dapat diambil kesimpulan sebagai berikut: (1) Tingkat Suku Bunga tidak berpengaruh jsecara parsial dan signifikan terhadap Harga Saham pada Sub-Sektor Perbankan di Bursa Efek Indonesia periode 2016-2019. (2) Nilai Tukar tidak berpengaruh secara parsial dan signifikan terhadap Harga Saham pada Sub-Sektor Perbankan di Bursa Efek Indonesia periode 2016-2019. (3) Inflasi tidak berpengaruh secara parsial dansignifikan terhadap Harga Saham pada Sub-Sektor Perbankan di Bursa Efek Indonesia periode 2016-2019. (4) Return On Assets (ROA) berpengaruh secara parsial tetapi tidak signifikan terhadapHarga Saham pada Sub-Sektor Perbankan di Bursa Efek Indonesia periode 20162019. (5) Dari hasil pengujianyang dilakukan pada Tingkat Suku Bunga, NilaiTukar, Inflasi, dan Return On Assets (ROA) Harga Sahampada Sub-Sektor Perbankan di Bursa Efek Indonesia periode20162019 diketahui bahwa variabel-variabel tersebut berpengaruh secara simultan.

\section{DAFTAR PUSTAKA}

Adnyana, Putu Widya Putra., Kadek Rai Suwena., I Nyoman Sujana (2017). Pengaruh tongkat inflasi, suku bunga dan kurs valuta asing terhadap return saham pada perusahaan property and real estate di bursa efek Indonesia periode 2012-2016. Jurnal Pendisikan Ekonomi Undiksha, Vol.9 No.2 
Akbar, Kausar (2018). Pengaruh nilai tukar dan inflasi terhadap harga saham di Jakarta Islamic Index (JII) (studi kasus Perusahaan Tambang periode 2010-2017). Universitas Islam Negeri Ar-Raniry Banda Aceh.

Andriana, Denny (2015). Pengaruh nilai tukar terhadap harga saham setelah initial public offering (IPO). Universitas Pendidikan Indonesia.

Ani, Ni Komang Santi, Trianasari, Wayan Cipta (2019). Pengaruh Roa Dan Roe Serta Eps Terhadap Harga Saham Sektor Farmasi Yang Terdaftar Di Bei. Jurnal Manajemen, Vol. 5 No. 2, Oktober 2019.

Efendi, Fiona Mutiara., Ngatno (2018). Pengaruh Return On Assets (ROA) Terhadap Harga Saham dengan Earning Per Share (EPS) sebagai Intervening (Studi Kasus pada Perusahaan Sub Sektor Tekstil dan Garmen yang terdaftar di Bursa Efek Indonesia Periode 2013-2016). Jurnal Administrasi Bisnis, Vol.7 No.1, Maret 2018.

Faoriko, Akbar (2013). Pengaruh inflasi, suku bunga dan nilai tukar rupiah, terhadap return saham di bursa efek Indonesia. Universitas Negeri Yogyakarta.

FARIANTIN, HJ. ERVIVA (2019). Pengaruh Return On Asset (Roa) Dan Net Profit Margin (NPM) Terhadap Harga Saham Pada Perusahaan Farmasi Tbk Yang Terdaftar Di Bursa Efek Indonesia. Sekolah Tinggi Ilmu Ekonomi AMM Mataram.

Ginting, Maria Ratna Marisa., Topiwijono., Sri Sulasmiyati (2016) Pengaruh Tingkat Suku Bunga, Nilai Tukar, dan Inflasi terhadap Harga saham (studi pada sub-sektor perbankan di Bursa Efek Indonesia periode 2011-2015 ). Jurnal Administrasi Bisnis, Vol.35 No.2 Juni 2016.

Ghozali, imam (2016). Aplikasi Analisis Multivariate dengan Program IBM SPSS 23. Ed. 8, Semarang : Badan penerbit Universitas Diponegoro.

Kewal, Suramaya Suci (2012). Pengaruh Inflasi, Suku Bunga, Kurs, dan Pertumbuhan PBD terhadap Indeks Harga Saham Gabungan. Jurnal Economia, Vol.8 No.1 April 2012.

Karim, Abdul. 2015. Analisis Pengaruh Faktor Internal Dan Eksternal Terhadap Return Saham Perusahaan Manufaktur Yang Terdaftar Di Bursa Efek Indonesia (Bei) Periode 2010-2012. Media Ekonomi dan Manajemen, 30(1): 41-55.

Harsono, Rezeki Ardelia., Saparila Worokinasih (2018). Pengaruh Inflasi, Suku Bunga, Dan Nilai Tukar Rupiah Terhadap Indeks Harga Saham Gabungan (Studi pada Bursa Efek Indonesia Periode 20132017). Universitas Brawijaya Malang

Hikmawati, Ningsih, Adi Wiratno., Suyanto, Darmansyah (2018). Pengaruh Return On Assets, Return On Equity, Debt To Equity Ratio, Inflasi, Dan Suku Bunga Terhadap Return Saham Pada Perusahaan Manufaktur Di Bursa Efek Indonesia (Studi Empiris Pada Perusahaan
Secondary Sectors Periode 2010-2015). Jurnal Ilmiah Akuntansi Kesatuan Vol. 6 No. 1, April 2018. Universitas Pancasila.

Ilmi, Maisaroh Fathul (2017.Pengaruh Kurs/ Nilai Tukar Rupiah, Inflasi Dan TingkatSuku Bunga Sbi Terhadap Indeks Harga Saham Gabungan Lq-45 Periode Tahun 2009-2013. Universitas Negeri Yogyakarta. Jurnal Nominal, Vol.6 No.1 2017.

Lisnawati, Eka Budiyanti (2011). Perkembangan Pasar Modal Dan Pertumbuhan Ekonomi Di Indonesia: Analisis Vector Autoregressions (VAR). Jurnal Ekonomi \& Kebijakan Publik, Vol. 2 No. 2 Desember 2011.

Maronrong, Ridwan, Kholik Nugrhoho (2017). Pengaruh inflasi, suku bunga dan nilai tukar terhadap harga saham stydi kasus pada perusahaan manufaktur otomotif terdaftar di bursa efek Indonesia tahun 2012-2017. Jurnal STEI Ekonomi, Vol.26 No.2, Desember 2017

Nurlina (2017). Pengaruh nilai tukar dan suku bunga terhadap harga saham PT. Bank Rakyat Indonesia Tbk. Jurnal Samudea Ekonomika, Vol.1 No.1 April 2017.

Putri, Linzzy Pratami (2017). Pengaruh Inflasi Dan Nilai Tukar Rupiah Atas Dollar AS Terhadap Kinerja Saham Perusahaan Property Dan Real Estate Di Indonesia. Universitas Muhammadiyah Sumatera Utara

Ramadani, Fitri (2018). Pengaruh Inflasi, Suku Bunga Dan Nilai Tukar Rupiah Terhadap Harga Saham Perusahaan Sektor Properti Dan Real Estate Yang Tercatat Di Bursa Efek Indonesia. Jurnal departemen Managemen FEB UMM

Revualu, Vicky Viktor (2018). Pengaruh Tingkat Suku Bunga Bank Indonesia Terhadap HargaSaham

Pada Perusahaan Pertambangan Yang Terdaftar Di Bursa Efek Indonesia. Diploma thesis, Universitas Negeri Makassar.

Saripudin, Hilman Lutfi (2017). Pengaruh Makro Ekonomi Terhadap Harga Saham Pada Perusahaan Sektor Perbankan di Bursa Efek Indonesia. Kalbisocio, Volume 4 No. 2 Agustus 2017.

Sorongan, Fangky A. (2019). Pengaruh Return On Assets, Return On Equity, Earning Per Share Terhadap Harga Saham Pada Perusahaan Otomotif Yang Terdaftar Bei. Jurnal Ilmiah Manajemen Bisnis dan Inovasi, Vol.6 No.2 MEI 2019

Sulia (2017). Analisis Faktor - Faktor Yang Mempengaruhi Harga Saham Pada Perusahaan Lq45 Yang Terdaftar Di Bursa Efek Indonesia. Jurnal Wira Ekonomi Mikroskil

Suriyani, Ni Kadek., Gede Mertha Sudiartha (2018). Pengaruh tingkat suku bunga, inflasi, dan nilai tukar terhadap return saham di burda efek Indonesia. E-Jurnal Manajemen Unud, Vol.7 
No.6A. Universitas Udayana, Bali, Indonesia. Fakultas Ekonomi dan Bisnis

Ukhriyawati, Catur Fatchu., Maya Pratiwi (2018). Pengaruh Return On Asset (ROA), Debt to Equity Ratio (DER), dan Earning Per Share (EPS) terhadap Harga Saham pada Perusahaan Properti di BEI. Universitas Riau Kepulauan. Jurnal Equilibiria Vol.5No.2 2018.

Viska, Yulia Vira., Aminar Sutra Dewi (2018). Pengaruh tingkat inflasi, suku bunga dan nilai kurs dollar AS terhadap indeks harga saham gabungan pada bursa efek Indonesia (BEI) periode 20112015. Sekolah Tinggi Ilmu Ekonomi KBPF

Wahyuningsih, Elvinia, Rita Andini, Agus Suprijanto (2018). Pengaruh tingkat suku bunga dan inflasi terhadap return saham dengan nilai tukar rupiah sebagai variabel intervening (studi kasus pada PT Astra Internasional Tbk periode 2011-2015). Fakultas Ekonomi Universitas Pandanaran Semarang

Wismantara, Sangga Yoga., Ni Putu Ayu Darmayanti (2017). Pengaruh nilai tukar, suku bunga dan inflasi terhadap indeks harga saham gabungan di bursa efek Indonesia. E-jurnal Manajemen Unud, Vol.6 No.8

Yuliawan (2016). Pengaruh tingkat suku bunga (SBI) dan inflasi terhadap IHSG industri perbankan yang terdaftsr di bursa efek Indonesia (BEI). Institut Ilmu Sosial dan Manejemen STIAMI. 